\title{
Skeletal system evaluation using RTG absorptiometry in women with bone mineral density disorders
}

\author{
Mieczysława U. Jurczyk, Katarzyna Dziekan, Katarzyna Wszołek, Karolina Chmaj-Wierzchowska \\ Department of Maternal and Child Health, Poznan University of Medical Sciences, Poznan, Poland
}

\begin{abstract}
Introduction: Osteoporosis is a metabolic disease of the skeleton, characterized by decreased bone mass and abnormal microarchitecture, which contribute to an increased risk of fractures. Currently, over 200 million people are struggling with it worldwide, and therefore it is considered a social disease. Many of the affected require constant help from others, which is often associated with an increase in the cost of health care.

Aim of the study: To analyze the role of prophylaxis in the improvement of bone mass density and the evaluation of various methods of treating bone mineral density (BMD) disorders in women.

Material and methods: The cohort study includes retrospective analysis of 105 patients documentation which were examined using the DXA densitometric method (Dual Energy X-Ray Absorptiometry) using LUNAR DPX equipment. The test results were given in $\mathrm{g} / \mathrm{cm}^{2}$ and presented using a T-score (SD average result for peak bone mass in young healthy women) and Z-score (SD mean score for the same group of women). The study included only women with BMD disorders. The analysis, the evaluation and statistical analysis are presented in Microsoft Excel, 2010. The bioethical commission agreement was not needed in this case.

Results: The largest group (55 surveyed patients) $-52.4 \%$, were women suffering from osteoporosis. Decreased BMD was less common in patients living in urban areas. Among patients who suffered from osteoporosis, severe bone pain in the whole body occurred most often.

Conclusions: In Polish society, the incidence of osteoporosis is increasing. The main reason is the aging of the population. The number of fractures associated with this ailment increases after the age of 60 . Analyzing the methods of treatment and assessing their effects on the reduced density of bone mass shows that the process of bone tissue disorders has deepened in non-treated patients.
\end{abstract}

Key words: osteoporosis, dual-beam absorption, densitometry, disturbances in the skeletal system of a human, female, prophylaxis.

\section{Introduction}

In a 40-year-old person, one can note a slow phenomenon of skeletal demineralization. This phenomenon, connected with aging, increases the risk of osteoporosis. Osteoporosis is a metabolic disease of the skeleton, characterized by a decreased bone mass and abnormal microarchitecture, which contribute to an increased risk of fractures and a significant reduction in the quality of life [1]. Osteoporosis is most common in women during menopause and in persons advanced in age. Currently, over 200 million are struggling with it worldwide, and therefore it is considered a social disease [2-4]. Patients afflicted with osteoporosis struggle with chronic pain, physical disability, and mental health issues. Many of the affected require constant help from others, which is often associated with an increase in the cost of health care. The abovementioned statistics show the very nature of the disease that works insidi- ously, without revealing its symptoms, possibly for several years [5-8].

The aim of this study was the analysis of the role of prophylaxis in the improvement of bone mass density and the evaluation of various methods of treating bone mineral density (BMD) disorders in women.

\section{Material and methods}

The study includes 105 patients who were treated and examined in the Densitometry Laboratory in the Gynecology and Obstetrics Hospital of the Poznan University of Medical Science. The statistical analysis of the results was made based on medical treatment data and continual diagnostics of patients who were diagnosed with/or suspected of bone mass density disorders. The study included only women with BMD disorders. In the conducted research, particular attention 
Table 1. Age of patients in particular degrees of disturbances in bone density

\begin{tabular}{lcc}
\hline Age range & Number of patients $(n)$ & Percentage \\
\hline \begin{tabular}{l} 
Patients diagnosed with osteopenia \\
\hline $21-30$
\end{tabular} & 9 & 45.0 \\
\hline $31-40$ & 6 & 30.0 \\
\hline $41-47$ & 2 & 15.0 \\
\hline $48-83$ & 3 & 10.0 \\
\hline Patients diagnosed with osteoporosis & \\
\hline $21-30$ & 5 & 5.5 \\
\hline $31-40$ & 27 & 9.0 \\
\hline $41-47$ & 20 & 49.1 \\
\hline $48-83$ & 1 & 36.4 \\
\hline Patients diagnosed with advanced osteoporosis & \\
\hline $21-30$ & 2 & 3.3 \\
\hline $31-40$ & 10 & 6.7 \\
\hline $41-47$ & 17 & 53.3 \\
\hline $48-83$ & 36.7 \\
\hline
\end{tabular}

Table 2. Characteristics of the surveyed group

\begin{tabular}{|c|c|c|}
\hline Characteristic & $\begin{array}{c}\text { Number } \\
\text { of patients }(n)\end{array}$ & Percentage \\
\hline \multicolumn{3}{|l|}{ Place of residence } \\
\hline Countryside & 60 & 57.1 \\
\hline $\begin{array}{l}\text { City population } \\
\text { up to } 100,000 \text { residents }\end{array}$ & 30 & 28.6 \\
\hline $\begin{array}{l}\text { City population over } \\
100,000 \text { residents }\end{array}$ & 15 & 14.3 \\
\hline \multicolumn{3}{|l|}{ BMI } \\
\hline Underweight & 50 & 47.6 \\
\hline Normal weight & 40 & 38.1 \\
\hline Excess weight & 10 & 9.5 \\
\hline Obesity & 5 & 4.8 \\
\hline \multicolumn{3}{|l|}{ Menstrual cycle } \\
\hline Postmenopausal cycle & 40 & 38.1 \\
\hline $\begin{array}{l}\text { Irregular menstrual } \\
\text { period }\end{array}$ & 30 & 28.6 \\
\hline Secondary amenorrhea & 20 & 19.0 \\
\hline $\begin{array}{l}\text { Regular menstrual } \\
\text { period }\end{array}$ & 15 & 14.3 \\
\hline \multicolumn{3}{|c|}{ Family history of the osteoporosis } \\
\hline Yes & 65 & 61.9 \\
\hline No & 40 & 38.1 \\
\hline \multicolumn{3}{|l|}{ Cigarette smoking } \\
\hline Yes & 63 & 60.0 \\
\hline No & 42 & 40.0 \\
\hline \multicolumn{3}{|l|}{ Prophylaxis } \\
\hline Yes & 30 & 28.6 \\
\hline No & 75 & 71.4 \\
\hline
\end{tabular}

was paid to the degrees of advancement of bone mass density disorders, assessment of the risk factors and their link with a decreased BMD, symptoms associated with these disorders and the treatment used and its effect on BMD. No other significant factors have been introduced within the above-mentioned studies which would exclude patients from participating. The analysis includes the following additional factors: age, residence, menstrual cycle, osteoporosis in the family, tobacco use, prophylaxis, symptoms accompanying specific degrees of disturbance. Furthermore, the study considers in detail the osteoporosis treatment itself and its effect on BMD values.

During the analysis, the study included the degree of severity of mass density disorder within the bone structure, which was determined based on the BMD (T-score) measurement results in the lumbar spine (L1L4) and femoral neck according to the criteria of diagnostic tests provided by the World Health Organization (WHO) $[9,10]$. The correct values are T-score between +1 and -1 . When this index is between -1 and -2.5 we deal with osteopenia, i.e. with a reduced amount of bone tissue with the balance between organic and inorganic. T-score, below -2.5 indicates osteoporosis. WHO's advanced osteoporosis occurs at a T-score below -2.5 , which low level is also accompanied by pathological low-energy fractures. In all 105 women tested, the test was performed using the DXA densitometric method (Dual Energy X-Ray Absorptiometry) using LUNAR DPX equipment. The test results were given in $\mathrm{g} / \mathrm{cm}^{2}$ and presented using a T-score (SD average result for peak bone mass in young healthy women) and Z-score (SD mean score for the same group of women). The analysis, the evaluation and statistical analysis are presented in Microsoft Excel, 2010.

\section{Results \\ The degree of advancement of the bone mass density disorders}

The largest group (55 surveyed patients, 52.4\%) were women suffering from osteoporosis. Advanced osteoporosis occurred in 28.6\% (30 surveyed patients). The smallest group were patients suffering from osteopenia (20 women), i.e. 19\% of the examined group. The age of the patients in individual degrees of disturbances in bone density was collected in Table 1 . Characteristics of the group the tested person is included in Table 2.

\section{Place of residence}

The highest morbidity associated with decreased BMD occurred in women who lived in rural areas (60 patients - 57.1\%). Decreased BMD was less common in patients living in urban areas. The study shows 
30 patients in cities with a population of up to 100,000 residents (28.6\%). In cities with a population of 100,000 or more residents, 15 patients were recorded (14.3\%) (Table 2).

\section{Symptoms that accompany specific groups of women with bone mass density disorder}

Among the patients suffering from osteopenia, the most common ailment was severe back-bone pain (present in $70 \%$ of women affected by osteopenia). Among patients who suffered from osteoporosis, severe bone pain of the whole body occurred most often, in as many as 38 women $-69.1 \%$ of the total group covered by the study. Among the patients who had advanced osteoporosis, half of the women (30) reported severe bone pain of the whole body along with osteoporotic fractures. Severe back-bone pain accompanied by a low energy trauma occurred in 9 patients - 30\% of patients with advanced osteoporosis (Table 3 ).

\section{Treatment}

Almost half of the women (49.5\%) did not undergo treatment after being diagnosed with the disorders of BMD. 28 patients $(26.7 \%)$ received treatment for osteoporosis. The medication included: supplementation of $1500 \mathrm{mg}$ of calcium, $25 \mu$ of vitamin D per day, bisphosphonates, calcitonin, and SERM medication. The above-mentioned osteoporotic treatment and concomitant hormonal treatment associated with systemic disorders Endocrine was used in 21 women, which constitutes $20 \%$ of the total number of respondents. Four patients (3.8\%) were treated hormonally only, without the use of other drugs which reduce bone resorption (Table 4).

\section{Treatment and assessment of its effects on the decreased density of bone mass}

For this purpose, the arithmetic average of twofold densitometric results of the tests section of the L1-L4 and femoral neck were compared, presented using T-score indicators. The results for women who never underwent treatment were compared with the results of women who were subjected to treatment. The first tests were done on women who did not undergo any treatment showed that the average T-score in the L1-L4 showed -2,26, in contrast to women who were treated where the T-score showed $-2,72$. In respect to the femoral neck, the untreated women scored $-2,65$ and treated women scored $-2,73$ (Table 5). Follow-up tests in the same groups showed that in the untreated women, the T-score showed -2.9 and in treated women -2.49 . On the one hand, one can notice that in the case
Table 3. The occurrence of pain symptoms among patients with disturbances in bone density

\begin{tabular}{|c|c|c|}
\hline Symptoms & $\begin{array}{c}\text { Number } \\
\text { of patients }(n)\end{array}$ & Percentage \\
\hline \multicolumn{3}{|c|}{ Type of symptoms in patients with osteopenia } \\
\hline A strong back bone pain & 14 & 70.0 \\
\hline $\begin{array}{l}\text { A strong bone pain } \\
\text { of the whole body }\end{array}$ & 6 & 30.0 \\
\hline $\begin{array}{l}\text { A strong back bone pain } \\
\text { and osteoporotic fracture }\end{array}$ & 0 & 0 \\
\hline $\begin{array}{l}\text { A strong bone pain of the } \\
\text { whole body and osteoporotic } \\
\text { fracture }\end{array}$ & 0 & 0 \\
\hline An osteoporotic fracture & 0 & 0 \\
\hline \multicolumn{3}{|c|}{ Type of symptoms in patients with osteoporosis } \\
\hline A strong back bone pain & 17 & 30.9 \\
\hline $\begin{array}{l}\text { A strong bone pain of the } \\
\text { whole body }\end{array}$ & 38 & 69.1 \\
\hline $\begin{array}{l}\text { A strong back bone pain and } \\
\text { osteoporotic fracture }\end{array}$ & 0 & 0 \\
\hline $\begin{array}{l}\text { A strong bone pain of the } \\
\text { whole body and osteoporotic } \\
\text { fracture }\end{array}$ & 0 & 0 \\
\hline An osteoporotic fracture & 0 & 0 \\
\hline \multicolumn{3}{|c|}{ Type of symptoms in patients with advanced osteoporosis } \\
\hline A strong back bone pain & 0 & 0 \\
\hline $\begin{array}{l}\text { A strong bone pain of the } \\
\text { whole body }\end{array}$ & 0 & 0 \\
\hline $\begin{array}{l}\text { A strong back bone pain and } \\
\text { osteoporotic fracture }\end{array}$ & 9 & 30.0 \\
\hline $\begin{array}{l}\text { A strong bone pain of the } \\
\text { whole body and osteoporotic } \\
\text { fracture }\end{array}$ & 15 & 50.0 \\
\hline An osteoporotic fracture & 6 & 20.0 \\
\hline
\end{tabular}

Table 4. Used treatment and possible treatment methods in the examined patients

\begin{tabular}{lcc}
\hline Treatment & $\begin{array}{c}\text { Number } \\
\text { of patients }(n)\end{array}$ & Percentage \\
\hline Without treatment & 52 & 49.5 \\
\hline $\begin{array}{l}\text { Osteoporosis treatment } \\
\text { without hormonal treatment }\end{array}$ & 28 & 26.7 \\
\hline $\begin{array}{l}\text { Osteoporosis treatment with } \\
\text { hormonal treatment }\end{array}$ & 21 & 20.0 \\
\hline Hormonal treatment & 4 & 3.8 \\
\hline
\end{tabular}

Table 5. Comparison of densitometry results of women never treated with the results of women treated before the treatment

\begin{tabular}{lcc}
\hline Parameters & $\begin{array}{c}\text { Never treated } \\
\text { women }\end{array}$ & $\begin{array}{c}\text { Women before } \\
\text { treatment }\end{array}$ \\
\hline $\begin{array}{l}\text { Arithmetic mean T-score } \\
\text { in the lumbar spine (L1-L4) }\end{array}$ & -2.63 & -2.72 \\
\hline $\begin{array}{l}\text { Arithmetic mean T-score } \\
\text { in the femoral neck }\end{array}$ & -2.65 & -2.73 \\
\hline
\end{tabular}


Table 6. Comparison of densitometry results of women never treated with the results of women treated after the implemented treatment

\begin{tabular}{lcc}
\hline Parameters & $\begin{array}{c}\text { Never treated } \\
\text { women }\end{array}$ & $\begin{array}{c}\text { Women after } \\
\text { treatment }\end{array}$ \\
\hline $\begin{array}{l}\text { Arithmetic mean T-score } \\
\text { in the lumbar spine (L1-L4) }\end{array}$ & -2.9 & -2.49 \\
\hline $\begin{array}{l}\text { Arithmetic mean T-score } \\
\text { in the femoral neck }\end{array}$ & -2.91 & -2.53 \\
\hline
\end{tabular}

of untreated women, the bone tissue disorders progressed. On the other hand, one can notice that bone tissue disorder has regressed in the group of women that received treatment (Table 6).

\section{Comparison of all types of treatment used in the patients' understudy for the purpose choosing the most effective in improving bone mineral density}

Again, the arithmetic averages of twofold densitometric results were compared section L1-L4 and femoral neck, presented using T-score indicators. The results of three groups of women were compared: those only treated with anti-osteoporosis drugs, treated with antiosteoporosis drugs and hormonal treatment and only hormonally treated. The first result studies took place before the implementation of the above-mentioned therapeutic methods. The second study was performed after the treatment.

Based on the first research, it appears that within the L1-L4 spine segment, the arithmetic average of T-scores in women treated with medications focused exclusively against osteoporosis was -2.83 , in those included both osteoporotic and hormonal treatment -2.79 , and in women treated using only hormonal medications -2.55 . However, in the field of the femoral neck in the same groups, arithmetic averages presented re- spectfully as $-2.91,-2.8,-2.48$. One can note that the process of bone disorders was the most advanced in the group of women treated with medicine exclusively ordered against osteoporosis. The condition of bone mass, in terms of its density, seems best in the group of women who were treated only hormonally (Table 7). The second study performed after the applied treatment and results from the fact that within the L1-L4 segment the arithmetic average of the T-score results in women treated with medicaments exclusively ordered against osteoporosis was -2.56 , in women who received both: osteoporotic and hormonal treatments -2.37 and in women-only hormonally treated $-2,53$. However, in the femoral neck, in those same groups, arithmetic averages were presented successively as $-2.68,-2.4,-2.5$. One can see that the process of bone tissue disorder has been most effectively overcome in patients treated with anti-osteoporosis combined with hormonal treatment. Results of densitometric tests have also improved in women who were treated with only anti-osteoporotic drugs, although their improvement was not as significant as in the previous group. Among the women treated with hormonal therapy, it can be noted that this therapy used without connection with other methods of treatment is, a treatment that inhibits further bone resorption, however, it does not yield such significant effects as those used in connection with other medications (Table 8).

\section{Discussion}

In Polish society, the incidence of osteoporosis is increasing. The main reason is the aging of the population. The risk of reduced bone mass increases by $2.0 \%$ every five years for people who are above 65 years old. Furthermore, an additional variable that influences the increased incidence of osteoporosis is the increase of

Table 7. Comparison of densitometric results of the surveyed women before applying the given therapeutic methods

\begin{tabular}{lccc}
\hline Parameters & $\begin{array}{c}\text { Women before osteoporotic } \\
\text { treatment without any } \\
\text { hormonal treatment }\end{array}$ & $\begin{array}{c}\text { Women before osteoporotic } \\
\text { treatment and before } \\
\text { hormonal treatment }\end{array}$ & $\begin{array}{c}\text { Women before hormonal } \\
\text { treatment }\end{array}$ \\
\hline $\begin{array}{l}\text { Arithmetic mean T-score } \\
\text { in the lumbar spine (L1-L4) }\end{array}$ & -2.83 & -2.79 & -2.55 \\
\hline $\begin{array}{l}\text { Arithmetic mean T-score } \\
\text { in the femoral neck }\end{array}$ & -2.91 & -2.8 & -2.48 \\
\hline
\end{tabular}

Table 8. Comparison of densitometric results of the surveyed women after applying the given therapeutic methods

\begin{tabular}{|c|c|c|c|}
\hline Parameters & $\begin{array}{c}\text { Women before osteoporotic } \\
\text { treatment without any } \\
\text { hormonal treatment }\end{array}$ & $\begin{array}{c}\text { Women after osteoporotic } \\
\text { treatment and after hormonal } \\
\text { treatment }\end{array}$ & $\begin{array}{c}\text { Women after hormonal } \\
\text { treatment }\end{array}$ \\
\hline $\begin{array}{l}\text { Arithmetic mean T-score in } \\
\text { the lumbar spine (L1-L4) }\end{array}$ & -2.56 & -2.37 & -2.53 \\
\hline $\begin{array}{l}\text { Arithmetic mean T-score in } \\
\text { the femoral neck }\end{array}$ & -2.68 & -2.4 & -2.5 \\
\hline
\end{tabular}


detection - this is due to easier access to research densitometers that you can undergo as part of preventive programs [11]. According to the presented research, among patients who suffered from osteoporosis the most numerous group, (49.1\%) of the respondents, constituted women ranging 41-47 years old. Among patients who suffered from advanced osteoporosis the most numerous group (56.7\%), were women ranging from 48-83 years old. Furthermore, Kuczera and Pluskiewicz [12] believe that the group most endangered by osteoporosis in the elderly. The number of fractures associated with this ailment increases after the age of 60. Analyzing the obtained results, it has been shown that the risk of fractures in the elderly is higher than in younger people. Barańska et al. [13] noted that after exceeding 30 years of age, the age at which the peak bone mass is reached, the process of gradual decrease of bone mass occurs.

Analyzing the influence of the place of residence on the patients affected by the reduced density of bone mass, it appears that the highest incidence associated with decreased bone mass density occurred in women who lived in rural areas. One can also find a correlation between an increased number of diseases in the rural areas and a lower level of information about the bone mass decrease. Place of residence according to Dąbska et al. [14], significantly differentiates the level of knowledge. Survey respondents living in rural areas possessed less knowledge of the bone mass reduction than the people living in cities. As a result of the neglect of prevention against osteoporosis, the detection rate, prevention and treatment of osteoporosis in rural areas is much lower than in the urban areas.

Almost half of the surveyed women affected by bone mass density disorders were found underweight (47.6\%). Bączyk [15] believes that low body weight and/ or low BMI index are important risk factors contributing to fractures in advanced age. Population analysis showed that the risk of any type of fracture increases with $\mathrm{BMI}<18.5$, corresponding to the age of the person suffering the fracture. The research shows compliance with the theorem of Barańska et al. [13], who believes that due to the low peak bone mass, as well as the reduced level of body fat, slim, small-body patients are more susceptible to occurrence osteoporosis, in contrast to heavy set women. However, it must be noted that BMI over 30, is not a factor protecting against the illnesses.

Beyazit and Pek [16] have shown that: the femoral and lumbar BMD measurements were associated with serum UA levels. Higher serum UA levels were found to have a protective effect on postmenopausal osteoporosis respective of inflammation and dietary factors.

In the conducted research, one can note a relationship between the fluctuation of hormones and a higher risk of osteoporosis. According to Barańska et al. [13], condition of the ovaries is associated with estrogen de- ficiency and therefore a risk factor for osteoporosis. Also, a prolonged absence of menstruation increases the risk of osteoporosis. The absence of menstruation affects negatively the positive effect of estrogens on the bone system, which is based on stimulation osteogenesis and inhibition of bone resorption. Estrogens regulate bone regeneration and constitute the basis for maintaining normal bone mass. The result of a steady reduction in bone weight constitutes the so-called breakage threshold. In this situation, even a minimal overload of the bone system can result in its damage [6].

Genetic conditions are also an important factor affecting the degree of bone loss. Patients whose mothers developed osteoporosis were observed to have a reduced BMD and increased propensity to fracture, especially during menopause. Epidemiological studies highlight the impact of previous occurrences of osteoporosis in the patient's mother and its influence on osteoporosis morbidity, as a factor favoring the occurrence of fractures. According to Bączyk [15], it results that family injuries were much more numerous in patients with osteoporosis and osteopenia they occurred successively in $38 \%$ and $34.4 \%$ of the subjects. Among healthy women, fractures occurred in $9.3 \%$. Also, Barańska et al. [13] believe that there is a relationship between the occurrence of certain genes and the development of BMD disorders.

The research shows that $60 \%$ of respondents with reduced bone mass declared that they smoke or smoked cigarettes regularly. Bączyk [15] notes that smoking has a very negative effect on bone metabolism. Smoking in children and adolescents reduces peak bone mass and increases the risk of osteoporosis. Furthermore, it leads to disorders in nutrition and slows down gonadal activity. Besides, Bieniek [17] shows that smoking is an important risk factor leading to osteoporosis, possibly as a result of an increase in exposure to cadmium. Exposure to this element affects the demineralization of bone tissue by reducing the synthesis of vitamin D in the kidneys, increasing the excretion of calcium from urine and disruption of its incorporation into the bones. Our studies have shown that the majority of patients affected by osteopenia, osteoporosis or advanced osteoporosis have not implemented any preventive measures, they constitute $71,4 \%$ of the surveyed patients. Only $28.6 \%$ of the whole group has implemented prophylaxis against reducing bone mass density in regular physical activity and high calcium diet. Chabaj-Kędroń et al. [1] note that regular physical exercise combined with a healthy diet including an adequate supply of calcium, vitamin D and proteins are the most appropriate ways to achieve the highest peak bone mass and the optimal support for the functioning of the musculoskeletal system.

Exercise (5 times a week for 30 minutes) is related to the improvement of the mechanical properties of the 
skeletal structure as a result of increased endurance, an increase in BMD and stabilizes bone mass. Also, physical activity helps to maintain general physical fitness, thus reducing the risk of falls [11].

A balanced diet can satisfy the total demand for calcium. The situation looks different when it comes to vitamin D, where apart from good nutrition, exposure to the sun's rays is also needed. The maintenance of the right level of calcium in the body is combined with the obligation to limit components that hurt its balance: excess phosphorus concerning calcium, sodium, caffeine, and proteins of animal origin. Sustainable calcium economy along with the appropriate level of vitamin D ensures the regular and appropriate supply of vitamin C, magnesium and potassium. Consumption of saturated fats as well as vitamin $\mathrm{K}$ according to demand, positively affects the quality and density of the bone marrow. Therefore, it can be concluded how invaluable help for the sick would be a refund of dietary advice [13].

Women with osteoporosis may also experience severe pain, which decreases their quality of life. Pain is most often the result of occurring compression fractures of the vertebral bodies and progressive secondary deformities. The back pain can come as a result of the overloading of muscles and soft tissue.

A vertebral fracture can cause a reduction in growth [11]. Many reports show related ailments with reduced bone mass density and W. Horst-Sikorska and Wawrzyniak [18] show that a signal of developing osteoporosis is a fracture, usually caused by a small injury. Osteoporotic fractures lead to an altered body structure and other ailments in patients, they also assume an asymptomatic form. Kowalik et al. [19] state that disorders of BMD may not show the symptoms for many years. In the first stage of the illness, the patient does not suffer pain. Then, chronic back pain occurs. In the final stages, the pain increases in the standing and sitting position, while lying and resting stops.

Platta [20] refers also to the problem of osteopenia itself - notes that the main symptoms are acute back pain, worsening over time. Osteopenia, like osteoporosis, often does not manifests itself by early symptoms.

Analyzing the methods of treatment and assessing their effects on the reduced density of bone mass shows that the process of bone tissue disorders has deepened in non-treated patients. The results of densitometric examinations showed an improvement in patients undergoing any treatment for disorders of bone mass density.

The last factor examined in the study composed of a comparison of all types of treatment used in the studied patients. The objective of this exercise was to select the most effective treatment in improving BMD.

The process of bone tissue disorders was most effectively inhibited in patients undergoing prophylactic treatment against osteoporosis with a combination of a hormonal treatment. Densitometric findings showed improvement in women after using osteoporotic drugs without hormone therapy, though not as much as the previous group.

Reviewing the outcome of treatment among the women treated with hormones, one could see that this therapy, while used without connection with other therapeutic methods, does not yield significant effects such as therapies used with other medicaments.

Badurski et al. [11] write that drug therapy has an influence on fundamental processes during bone remodeling, i.e. on resorption - antiresorptive treatment, as well as bone formation - anabolic treatment. In the course of this therapy, BMD improves and increases mechanical strength. Also, each of the drugs that inhibit resorption, works actively in other tissues, combating the risk of other diseases, i.e. breast cancer or atherosclerosis.

Szeliga et al. [21] think that estrogens exert an influence on skeletal homeostasis during growth and adulthood. Regulation of osteoclasts and osteoblasts generation and apoptosis and prolongation of the lifespan of osteocytes are some of their actions on bone metabolism. Premature ovarian insufficiency (POI) and associated loss of estrogen action on osteoclasts leads to trabecular perforation and loss of connectivity.

A significant number of antiresorptive medicaments contrasts with a small number of bone-building agents. Meanwhile, only these drugs, through their anabolic effects give a chance to rebuild the bone structure and reduce the likelihood of the appearance of further fractures, in patients with advanced osteoporosis. In studies on the efficiency of bisphosphonates, Bączyk [15] showed that there is a positive relationship between BMD and bisphosphonate therapy. Badurski et al. [6] touched on the subject of hormonal treatment. According to their studies, estrogens slow down the accelerated rotation bone associated with menopause and prevent loss of bone mass in all skeleton places, regardless of age and duration of treatment. Long-term use hormone replacement therapy is unfortunately unfavorable to the body due to the risk of coronary heart disease, breast cancer, endometrium cancer, thromboembolism, stroke - despite the protective effect on the bones. Therefore, it is not currently recommended to utilize the hormone replacement therapy as the first choice in prevention and treatment osteoporosis. Bączyk also mentions Karzewnik and Sewerynka in his study and their co-authors. They proved the effectiveness of hormone replacement therapy in monotherapy and combined therapy with osteoporotic drugs, on BMD in patients with disturbances in bone mass. After a year of observation, a beneficial effect was also recognized in hormone replacement therapy as well as in combination therapy for BMD in recorded patients. An increase in BMD was demonstrated in patients treated with combined therapy in contrast to monotherapy. Włodarek [22] emphasizes the importance of an ade- 
quate supply of calcium and vitamin D in a diet, which has a positive influence on maintaining BMD in women during premenopausal and postmenopausal periods.

As shown in our study, a decline in bone density was significantly slower in pre-menopausal women who consumed significant amounts of dairy products which in turn, increased the supply of calcium and vitamin D. The situation was presented differently in patients who did not use a milk diet. Additional calcium supply reduces bone loss in pre-menopausal women. In this nutritional period intervention affects the proper bone mineralization, though the biggest influence is the change in estrogen levels in the body.

\section{Conclusions}

Osteoporosis is an important and growing issue in the modern world, where the number of cases is increasing on yearly bases, mainly as a result of the preexisting problem of aging of society.

The clinical diagnosis is of great importance in the fight against bone mass disorders, and above all, useful is Dual Energy X-Ray Absorptiometry (DEXA), which in Poland is a standard method of measuring BMD.

In combating bone mass density disorders, a significant effect of prophylaxis has proper nutrition, regular physical activity, pharmacological treatment and hormone therapy correcting menstrual disorders and medicines retarding bone resorption.

\section{Disclosure}

The authors report no conflict of interest.

\section{References}

1. Chabaj-Kędroń H, Dardzińska J, Małgorzewicz S. Osteoporoza jako choroba społeczna i cywilizacyjna - metody profilaktyki. Hygeia Public Health 2016; 51: 23-30.

2. Abramowicz P, Białokoz-Kalinowska I, Konstantynowicz J, et al. Dieta w profilaktyce osteoporozy - zalecenia i kontrowersje. Pediatr Med Rodz 2013; 9: 350-356.

3. Bieniec W, Jarząb J, Kijonka C, et al. Biochemiczne wskaźniki przebudowy kości. Diagn Lab 2008; 44: 269-277.

4. Bolanowski M, Leszczyński P. Nowe rekomendacje ISCD dotyczące wykonywania i interpretacji badań densytometrycznych metodą DXA Endokrynol Pol 2004; 6, 55: 744-748.

5. Adler R, Bilezikian J, Bolognese M, et al. Kliniczne rozpoznanie osteoporozy. Osteoporos Int 2014; 25: 1439-1443.

6. Badurski J, Czerwiński E, Marcinowska-Suchowierska E. Osteoporoza ocena ryzyka złamania. Post Nauk Med 2008; 6: 335-359.

7. Buczkowski K, Chlabicz S, Horst-Sikorska W, et al. Osteoporoza. Postępowanie profilaktyczne, diagnostyczne i lecznicze. Wytyczne dla lekarzy podstawowej opieki zdrowotnej. Forum Med Rodz 2012; 6: 153-160.

8. Charzyńska A. Osteoporoza jako istotny problem społeczny leczenie i rehabilitacja. Praca licencjacka. Wyższa Szkoła Rehabilitacji w Warszawie, Warszawa 2011.

9. Bręborowicz GH. Osteoporoza. In: Ginekologia i położnictwo. PZWL Warszawa 2007: 887-897.

10. Czerwiński E. Z osteoporozą na Ty. Krakowskie Centrum Medyczne, Kraków 2003.
11. Badurski J, Czerwiński E, Marcinkowska-Suchowierska E, et al. Osteoporoza - diagnostyka i terapia u osób starszych. Post Nauk Med 2011; 24: 410-423.

12. Kuczera W, Pluskiewicz W. Osteoporoza starcza. Ann Acad Med Siles 2012; 66: 57-65.

13. Barańska A, Dziedzic M, Janiszewska M, et al. Osteoporoza jako problem społeczny - patogeneza, objawy i czynniki ryzyka osteoporozy pomenopauzalnej. Probl Hig Epidemiol 2015; 96: 106-114.

14. Dąbska O, Firlej E, Janiszewska M, et al. Wiedza kobiet leczących się z powodu osteoporozy na temat ogólnej wiedzy o chorobie i czynników jej ryzyka. J Educ Health Sport 2016; 6: 255-265.

15. Bączyk G. Ocena jakości życia uwarunkowanej stanem zdrowia kobiet z obniżoną gęstością mineralną kości w okresie pomenopauzalnym. Rozprawa habilitacyjna. Wydawnictwo Naukowe Uniwersytetu Medycznego im. Karola Marcinkowskiego w Poznaniu, Poznań 2013.

16. Beyazit F, Pek E. Effects of vitamin B12, folate, uric acid, and serum biomarkers of inflammation on bone mineral density in postmenopausal women. Prz Menopauzalny 2018; 17: 69-76.

17. Bieniek A. Studium mineralogiczne zjawiska osteoporozy głowy kości udowej człowieka w nawiązaniu do rentgenowskich badań densytometrycznych. Rozprawa doktorska. Akademia Górniczo-Hutnicza im. Stanisława Staszica, Kraków 2012.

18. Horst-Sikorska W, Wawrzyniak A. Osteoporoza starcza. Pol Arch Med Wewn 2008; 118: 59-62.

19. Kowalik T, Lewandowski A, Siedlaczek M, et al. Ocena stanu wiedzy pacjentów na temat profilaktyki osteoporozy. J Educ Health Sport 2015; 5, 12: 503-520.

20. Platta A. Rola żywienia w profilaktyce i leczeniu osteopenii i osteoporozy u kobiet. Zeszyty Naukowe Akademii Morskiej w Gdyni 2014; 86: 16-28.

21. Szeliga A, Maciejewska-Jeske M, Męczekalski B. Bone health and evaluation of bone mineral density in patients with premature ovarian insufficiency. Prz Menopauzalny 2018; 17: 112-116.

22. Włodarek D. Znaczenie diety w zapobieganiu osteoporozie. Endokrynol Otył Zab Przem Mat 2009; 5: 245-253. 